\title{
OPEN Absorption, translocation, and effects of Bt Cry1AC peptides from transgenic cotton to the intercrops and soil functional bacteria
}

\begin{abstract}
Wei Zhang ${ }^{1,2}$, Zhen $\mathrm{Cao}^{1,2}$, Mian Wang ${ }^{1}$, Xiaojiao Chen ${ }^{1 \bowtie}$ \& Baomin Wang ${ }^{1 \bowtie}$
Insecticidal proteins encoded by the truncated genes from Bacillus thuringiensis ( $B t$ ) in transgenic crops are released into soil mainly through root exudate and crop residues. In the present study, Bt Cry1Ac protein was hydrolyzed by pronase that was secreted by the soil bacterium Streptomyces griseus. Six peptides were identified as the products of enzymatic hydrolysis by nano liquid chromatography tandem mass spectrometry (LC-MS/MS). One of the six peptides was labeled with radioactive isotope iodine- 125 and then purified. The ${ }^{125} \mathrm{I}$-peptide solution was irrigated to the rhizosphere soil of watermelon seedlings (Citrullus lanatus L.) and wheat seedlings (Triticum aestivum L.), which the two crops usually intercrop with cotton in China. Detection of radioactivity in both plant tissues within one hour proved adsorption, uptake and translocation of the peptide into watermelon and wheat seedlings. Three of the identified peptides were sprayed onto the seedling leaves of watermelon, wheat and maize (Zea mays L.) in the field or the growth chamber. No significant effects on plant growth were observed. These peptides also did not affect growth of organic phosphatedissolving, nitrogen-fixing, and potassium-dissolving bacteria in the culture. This study provides a new view of GMO risk assessment methodology.
\end{abstract}

Bt cotton, producing Bacillus thuringiensis $(\mathrm{Bt})$ toxins and thus reducing insecticide usage ${ }^{1}$, has been widely cultivated around the world. Bt protein toxins are released into soil from root exudate ${ }^{2}$, decayed biomass ${ }^{3}$, pollens ${ }^{4}$ and animal manures ${ }^{5}$. The repeated and large-scale cultivation of Bt crops could result in the accumulation of Bt protein in soil ${ }^{6}$. The studies of Bt protein accumulation in soil have been mainly focused on the content and half-life ${ }^{7,8}$. The concentrations of Bt protein have been detected in a range from 5 to $100 \mathrm{ng} / \mathrm{g}^{9}$ or from 200 to $300 \mathrm{ng} / \mathrm{g}$ in soil ${ }^{10}$. Head et al. ${ }^{7}$ estimated that plant biomasses contribute at least $650 \mathrm{ng} / \mathrm{g}$ of Cryl Ac protein in a Bollgard ${ }^{\circ}$ cotton field. Cry1 Ab toxin concentrations decrease to $38 \%$ of the initial concentration after 40 days and to $0.3 \%$ in 200 days $^{3}$. The degradation half-life $\left(\mathrm{DT}_{50}\right)$ of Bt protein is approximately 240 days in the tissues of transgenic corn, cotton and potato ${ }^{11}$. Moreover, Bt proteins bond rapidly and tightly to clays and organic matters in soil ${ }^{6,12}$. Such binding reduces the biodegradability and increases the persistence of Bt proteins ${ }^{12,13}$. Therefore, Bt proteins may remain biological activities for over hundreds of days in soil.

Numerous studies have been reported the effects of different Bt crops on microbes ${ }^{6,14-17}$, algae ${ }^{6}$, earthworms $s^{6,18}$, terrestrial isopods ${ }^{19}$, nematodes ${ }^{6,16,20}$, protozoa ${ }^{6,16}$, corn rootworms $^{20}$ and arthropods ${ }^{20,21}$ in soils. The bacterial communities and mycorrhizal establishment are lower obviously in the Bt-corn planted field ${ }^{14}$. The pre-symbiotic hyphal growth in root exudates and appressoria of Bt 176 transgenic maize are significantly decreased in comparison with the non-transgenic plants ${ }^{22}$. However, a majority of the studies indicated that Bt proteins have no or negligible impact on soil ecosystem ${ }^{15-17,19,20,23}$. The Bt toxins from three subspecies including Bacillus thuringiensis subsp. Kurstaki (Btk), B. thuringiensis subsp. Morrisoni strain Tenebrionis (Btt) and B. thuringiensis subsp. Israelensis (Bti) did not inhibit the growth of bacteria, fungi, yeasts, algae and cyanobacterium ${ }^{17}$. The soil planted with Bt corn did not show the change in the numbers of some soil mites, collembola, and nematodes ${ }^{20}$. Under field conditions, there is little difference in microflora between Bt-potato plants and commercial potato plants ${ }^{15}$.

${ }^{1}$ College of Agriculture and Biotechnology, China Agricultural University, Yuanmingyuan west road No.2, Beijing 100193, China. ${ }^{2}$ These authors contributed equally: Wei Zhang and Zhen Cao. ${ }^{\square}$ email: chenxj913@126. com; wbaomin@263.net 

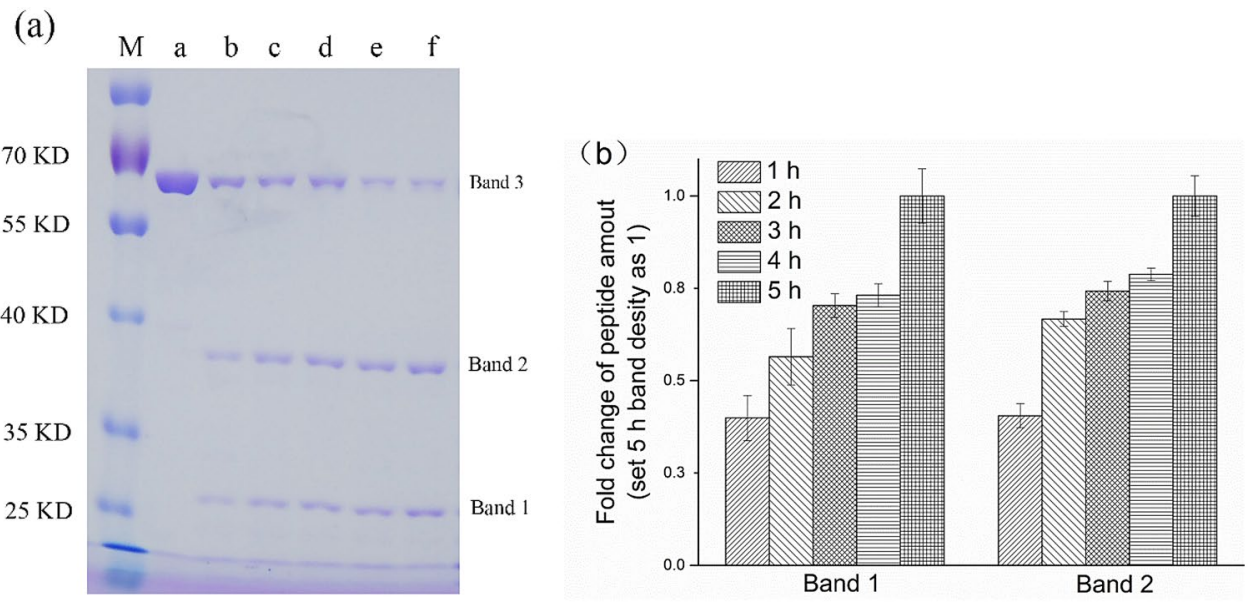

Figure 1. (a) Pronase enzymolysis results of Bt CrylAc protein. SDS image of pronase-digests of Bt CrylAc protein. Bt CrylAc $(0.25 \mathrm{mg} / \mathrm{mL})$ was digested with pronase $(0.01 \mathrm{mg} / \mathrm{mL})$ at incubation temperature of $37^{\circ} \mathrm{C}$ for 0 (a), 1 (b), 2 (c), 3 (d), 4 (e) and 5 (f) hours. M, pre-stained protein ladders. Bands 1 and 2 are digest peptides of Bt Cry1Ac (band 3). (b) Densitometric analysis of peptides Band 1 and 2 of SDS-PAGE. Optical density was normalized to each $5 \mathrm{~h}$ Band's value, respectively.

The laboratory studies showed little adverse effects of Cry1 Ab transgenic maize leaves on Trachelipus rathkii and Armadillidium nasatum ${ }^{19}$. The different effects may be related to Bt protein content and bacterial community.

In 2015, China planted about 3.7 million hectares of Bt-cotton, being $96 \%$ of its 3.8 million total cotton acreage $^{24}$. Cotton-based intercropping, such as wheat-cotton, is a common practice ${ }^{25}$. Cotton is often intercropped with peanut, soybean, chickpea, onion, radish, chills ${ }^{26}$, watermelon ${ }^{27}$, jujube and apricot. Microorganisms in soil can utilize free and clay-bound Bt proteins as the carbon source and energy ${ }^{28-30}$. Bt proteins can be enzymatically digested, such as by bacterial and fungal proteases, into peptides and degraded proteins $\mathrm{s}^{31}$. Streptomyces griseus, for example, can produce the proteolytic enzyme pronase ${ }^{32}$. Effects of peptides derived from Bt protein on soil bacteria remain unclear. In field circumstances, Bt proteins are degraded into small peptides or free amino acids. The uptake of the Bt protein by various crops from soils on which Bt corn had previously grown was reported ${ }^{33,34}$. However, few studies on absorption, uptake and translocation of metabolic peptides of Bt proteins into intercrops were conducted. In the present study, we identified some peptides of Bt protein hydrolyzed by soil bacteria secreted enzymes, studied the uptake and translocation of the peptides to other crops, and investigated toxic effects of these peptides on soil bacteria.

\section{Results}

Enzymolysis of Bt Cry1Ac and identification of peptides. The SDS-PAGE image showed the Bt CrylAc protein was digested into band 1 and band 2 by pronase (Fig. 1a). The amounts of band 1 and band 2 enhanced with the increase of digestion time $(0-5 \mathrm{~h})$ (Fig. 1b). Both $\mathrm{N}$-terminal amino acid sequencing and nanoLC-MS/MS analysis were used to confirm the degraded proteins (bands 1 and 2 in Fig. 1a). The peptides $\mathrm{NH}_{2}$-GINNQQLSVL-COOH and $\mathrm{NH}_{2}$-ETPYTPIDIS-COOH from bands 1 and 2, respectively, identically matched with the amino acid sequences of 374-383 and 30-39 of Bt Cry1Ac. In addition, after $5 \mathrm{~h}$ of digestion by pronase, peptides consisting about 10 amino acids were determined in triplicate by nanoLC MS/MS. Seven, eight and ten peptides in such size were identified in three technical replicates. Eleven peptides were identified (Table 1), and Peptide A, B, C, D, E, F were identified in all three technical replicates (Fig. 2).

The digest yields of low-molecular-weight peptide were identified by nanoLC MS/MS in technical triplicate. Among the 11 peptides identified, peptides A-F were detected in all three replicates and peptides $\mathrm{G}-\mathrm{K}$ were detected in one or two of the three replicates.

Radioactive iodination. The peptide B ( $\mathrm{NH}_{2}$-YTNPVLEN-COOH) was radioactively iodinated (Fig. 3c). Two distinct radioactive peaks showed at retention times (Rt) of 4.969 and $7.838 \mathrm{~min}$ (Supplementary Fig. S1), which the former was unincorporated radioactive iodine and the latter was the iodinated peptide of interest. The radioactivity of the former and latter accounted for $46.4 \%$ and $53.6 \%$, respectively, which indicated $53.6 \%$ of radioactive iodination yield and no side reactions.

Transferability of peptide from soil to plant. The ${ }^{125} \mathrm{I}$-peptide was infiltrated into rhizosphere soil. Radioactivity in leaf and stem tissues of wheat and watermelon seedlings was detected at one hour after sprayings of the ${ }^{125}$ I-peptide (Fig. 3a,b), indicating that peptide B was transferred from soil to plants. In general, the radioactivity in wheat tissues was higher than that in watermelon and the intensity of radiation in stems of both wheat and watermelon was strong compared with that in leaves (Fig. 3a,b). The radioactivity level in their tissues after five hours of ${ }^{125}$ I-peptides fertilization was showed in Supplementary Table S3. Radioactivity in watermelon tissues was two- to ten-fold lower than that in wheat at the three radioactivity application levels 


\begin{tabular}{|l|l|l|c|}
\hline No & Sequence $(\boldsymbol{N}-\boldsymbol{C})$ & Number of amino acids & Molecular weight \\
\hline Peptide A & F.NDMNSALTT.A & 9 & 966.4 \\
\hline Peptide B & Y.TNPVLEN.F & 7 & 786.4 \\
\hline Peptide C & M.GNAAPQQR.I & 8 & 841.4 \\
\hline Peptide D & F.SNTVPATATSLDN.L & 13 & 1290.6 \\
\hline Peptide E & T.ATSLDNLQSSD.F & 11 & 1150.5 \\
\hline Peptide F & T.SLDNLQSSD.F & 9 & 978.4 \\
\hline Peptide G & D.SLDEIPPQNN.N & 10 & 1126.5 \\
\hline Peptide H & L.DEIPPQNNNVPPRQG.F & 15 & 1674.8 \\
\hline Peptide I & F.SNTVPATAT.S & 9 & 861.4 \\
\hline Peptide J & F.SNTVPATATS.L & 10 & 948.5 \\
\hline Peptide K & Y.TNPVLENFDGS.F & 11 & 1192.5 \\
\hline
\end{tabular}

Table 1. Peptides identified by nanoLC-MS/MS. Pronase digestion sites were indicated with a period sign (.).

1 MDNNPNINECIPYNCLSNPEVEVLGGERIETGYTPIDISLSLTQFLLSEF 51 VPGAGFVLGLVDIIWGIFGPSQWDAFLVQIEQLINQRIEEFARNQAISRL

101 EGLSNLYQIYAESFREWEADPTNPALREEMRIQF NDMNSALTTAIPLFAV

151 QNYQVPLLSVYVQAANLHLSVLRDVSVFGQRWGFDAATINSRYNDLTRLI

201 GNYTDYAVRWYNTGLERVWGPDSRDWVRYNQFRRELTLTVLDIVALFPNY I Peptide C

251 DSRRYPIRTVSQLTREIYTNPVLENFDGSFRGSAQGIERSIRSPHLMDIL

301 NSITIYTDAHRGYYYWSGHQIMASPVGFSGPEFTFPLYGTM SNAAPQQR

351 VAQLGQGVYRTLSSTLYRRPFNIGINNQQLSVLDGTEFAYGTSSNLPSAV

401 YRKSGTVDSLDEIPPQNNNVPPRQGFSHRLSHVSMFRSGFSNSSVSIIRA

451 PMFSWIHRSAEFNNIIASDSITQIPAVKGNFLFNGSVISGPGFTGGDLVR

501 LNSSGNNIQNRGYIEVPIHFPSTSTRYRVRVRYASVTPIHLNVNWGNSS

551 FNTVPATATSLDNLQSSEFGYFESANAFTSSLGNIVGVRNFSGTAGVII

601 DRFEFIPVTATLEAEYNLERAQKAVNALFTSTNQLGLKTNVTDYHIDQ

\author{
○eptide A \\ Peptide B \\ 口Peptide D \\ 口Peptide E \\ DPeptide F
}

Figure 2. The locus of confirmed degraded peptides from Bt CrylAc protein. Peptides identified by nanoLC-MS/MS after Bt CrylAc was digested with pronase for $5 \mathrm{~h}$ at $37^{\circ} \mathrm{C}$. Peptide A $\left(\mathrm{N}^{135} \mathrm{DMNSALTT}{ }^{143}\right)$; peptide $\mathrm{B}\left(\mathrm{T}^{269} \mathrm{NPVLEN}^{275}\right)$; peptide $\mathrm{C}\left(\mathrm{G}^{342} \mathrm{NAAPQQR}{ }^{349}\right)$; peptide $\mathrm{D}\left(\mathrm{S}^{552} \mathrm{NTVPATATSLDN}^{564}\right)$; peptide E $\left(\mathrm{A}^{559} \mathrm{TSLDNLQSSD}^{569}\right)$; peptide F $\left(\mathrm{S}^{561} \mathrm{LDNLQSSD}^{569}\right)$.
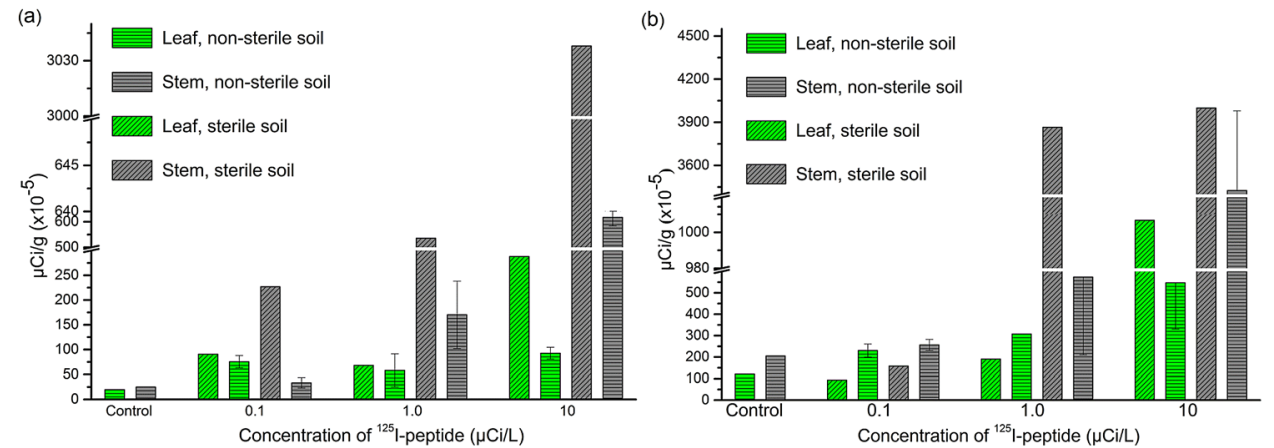

(C)

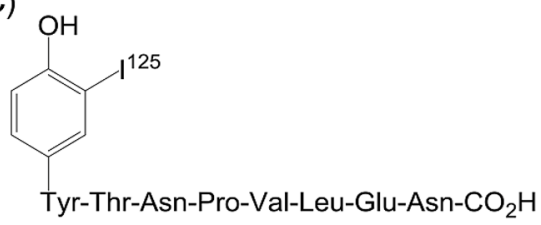

Figure 3. ${ }^{125}$ I-peptide transferred from soil to leaves and stems. Absorption, uptake and translocation of ${ }^{125}$ I-labelled peptide YTNPVLEN (c) from soil to leaves and stems. Radioactivity value was detected in leaf (green) and stem (grey) of watermelon (a) and wheat (b) seedlings after application of ${ }^{125}$ I-peptide one hour later. Radioactivity value of plants cultivated in sterile soil (twill) was significantly higher than that in non-sterile soil (horizontal stripes). 

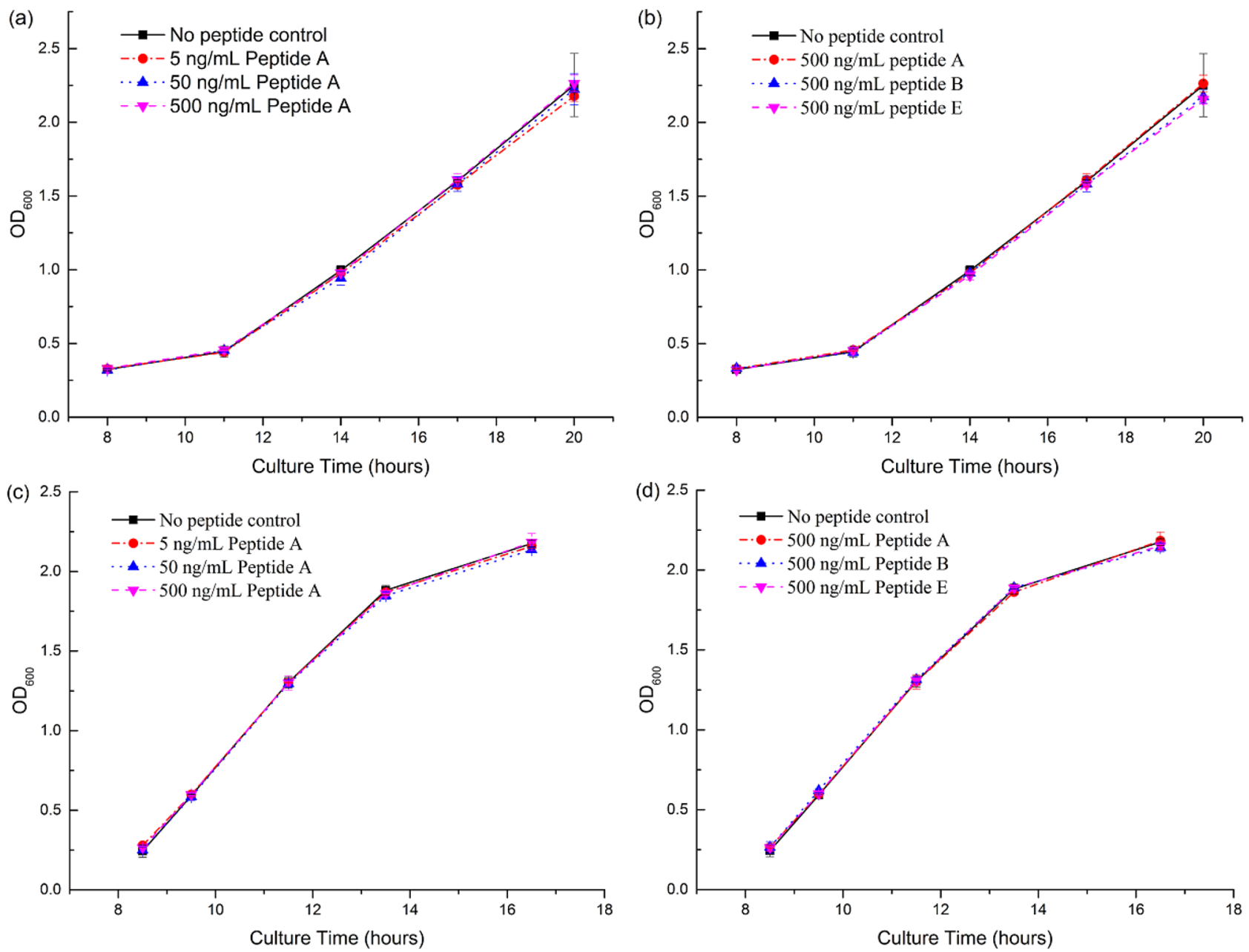

Figure 4. Effect of peptides on bacteria growth in liquid medium. Growth of organic phosphate-dissolving (OPD) bacteria (a,b) and nitrogen-fixing (NF) bacteria (c,d) by utilizing pronase-digested peptides (A, B, and E) supplemented in medium III (OPD bacteria) or medium V (NF bacteria). Every group has three replicates.

$(0.1,1.0$ and $10 \mu \mathrm{Ci} / \mathrm{L})$, except that the radioactivity in stems of watermelon and wheat was roughly similar at the $10 \mu \mathrm{Ci} / \mathrm{L}$ level in the sterile soil. The ${ }^{125} \mathrm{I}$-peptide content in wheat tissues were in the magnitudes of $1.0 \times 10^{-15}$ and $1.8 \times 10^{-14} \mathrm{~mol} / \mathrm{g}$ (fresh weight). The radioactivity of plants cultivated in sterile soil was significantly higher than that in non-sterile soil.

Effect of peptides on soil fertility related bacteria and on physiology of wheat, watermelon and maize. The bacterial species, including phosphate-dissolving, nitrogen-fixing bacteria and potassiumdissolving bacteria, were isolated from soil and identified by alignment of 16S rRNA gene sequence (Supplementary Table S1). Peptides A, B and E at a concentration up to $500 \mathrm{ng} / \mathrm{mL}$ had no obvious effects on the growth of phosphate-dissolving and nitrogen-fixing bacteria (Fig. 4, data was showed in Supplementary Table S2) and potassium-dissolving bacteria (Fig. 5). In addition, those peptides had no significant effect on total soluble protein, total sugar, chlorophyll, superoxidedismutase and phenotype of watermelon, wheat and maize, except that chlorophyll b significantly increased by $9.1 \%$ in peptide B-treated watermelon (Table 2).

\section{Discussion}

The fate and risk of Bt protein have been controversial. The concentrations of Bt protein varied considerably in the rhizosphere of transgenic Bt crops during entire growth season ${ }^{10}$. Some studies indicated accumulation and persistence of Bt proteins in soil ${ }^{5,35}$. The other studies showed that Bt protein can be degraded soon in field soil and no accumulation after multiple years of transgenic crop use $\mathrm{e}^{7,8}$. Many scientists found the risk of Bt protein to soil ecosystem was very significant ${ }^{14,22}$. The other studies suggested negligible risk of Bt protein in soil from Bt crops ${ }^{2,15-17,19,20,23}$.

Few studies on enzyme digestion of Bt proteins in soil have been reported ${ }^{31}$. Studies of the fate of Bt proteins in soil have had several challenges. Bt protein can be adsorbed and tightly bound on the clay minerals ${ }^{35,36}$, montmorillonite and kaolinite ${ }^{28}$, clay-size fraction and humic acids ${ }^{6,12,13}$. It is therefore difficult to extract Bt protein or its peptides from soil ${ }^{23}$. Substantial interfering substances in soil can cause interference problems ${ }^{37}$. A fortification study of pure CrylAc protein into soil would need a large amount of pure protein, which is costly 


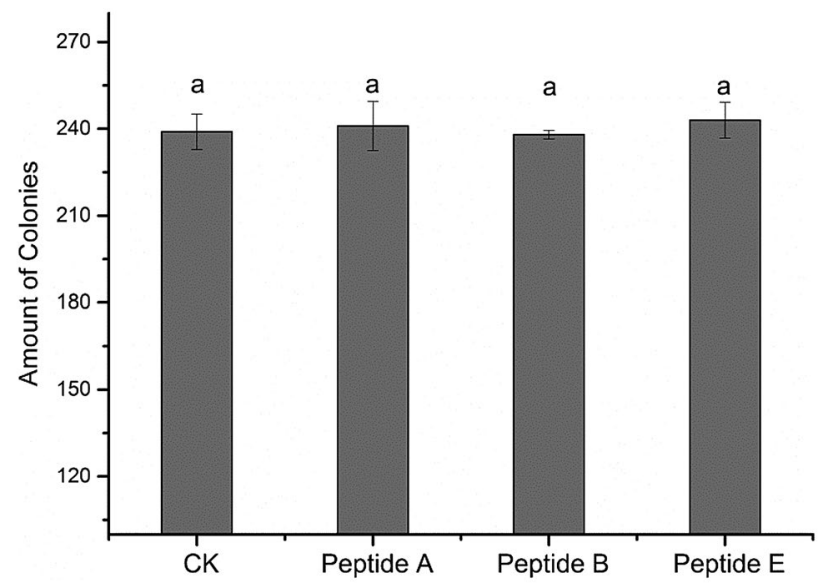

Figure 5. Colony number of potassium-dissolving bacteria after peptides treatment. Number of potassiumdissolving (PD) bacteria colonies after supplementation of the peptides A, B and E in medium IV. Every group had three replicates. The same letter indicated no statistical significance at $\mathrm{P}<0.05$ as determined by the LSD test.

\begin{tabular}{|c|c|c|c|c|c|c|}
\hline Groups & Treatments & $\operatorname{SOD}(\mathrm{U} / \mathrm{g})$ & $\begin{array}{l}\text { Total soluble protein } \\
(\mathrm{mg} / \mathrm{g})\end{array}$ & Total sugar (mg/g) & Chlorophyll a (mg/g) & $\begin{array}{l}\text { Chlorophyll b } \\
\text { (mg/g) }\end{array}$ \\
\hline \multirow{4}{*}{ Watermelon } & Control & $124.6 \mathrm{a}$ & $8.31 \mathrm{a}$ & $1.09 \mathrm{a}$ & $1.31 \mathrm{a}$ & $0.55 b$ \\
\hline & Peptide A & $123.7 \mathrm{a}$ & $8.42 \mathrm{a}$ & $1.09 \mathrm{a}$ & $1.34 \mathrm{a}$ & $0.57 \mathrm{ab}$ \\
\hline & Peptide B & $126.5 \mathrm{a}$ & $8.32 \mathrm{a}$ & $1.10 \mathrm{a}$ & $1.34 \mathrm{a}$ & $0.60 \mathrm{a}$ \\
\hline & Peptide E & $121.5 \mathrm{a}$ & $8.01 \mathrm{a}$ & $1.08 \mathrm{a}$ & $1.32 \mathrm{a}$ & $0.55 b$ \\
\hline \multirow{4}{*}{ Wheat } & Control & $126.8 \mathrm{a}$ & $3.86 \mathrm{a}$ & $1.32 \mathrm{a}$ & $1.42 \mathrm{a}$ & $0.42 \mathrm{a}$ \\
\hline & Peptide A & $124.4 \mathrm{a}$ & $3.82 \mathrm{a}$ & $1.32 \mathrm{a}$ & $1.42 \mathrm{a}$ & $0.43 \mathrm{a}$ \\
\hline & Peptide B & $125.3 \mathrm{a}$ & $3.81 \mathrm{a}$ & $1.32 \mathrm{a}$ & $1.41 \mathrm{a}$ & $0.42 \mathrm{a}$ \\
\hline & Peptide E & $125.4 \mathrm{a}$ & $3.83 \mathrm{a}$ & $1.33 \mathrm{a}$ & $1.41 \mathrm{a}$ & $0.43 \mathrm{a}$ \\
\hline \multirow{4}{*}{ Maize } & Control & $80.0 \mathrm{a}$ & $11.50 \mathrm{a}$ & $1.66 \mathrm{a}$ & $2.33 \mathrm{a}$ & $0.68 \mathrm{a}$ \\
\hline & Peptide A & $76.0 \mathrm{a}$ & $11.02 \mathrm{a}$ & $1.66 \mathrm{a}$ & $2.37 \mathrm{a}$ & $0.66 \mathrm{a}$ \\
\hline & Peptide B & $76.4 \mathrm{a}$ & $11.73 a$ & $1.67 \mathrm{a}$ & $2.46 \mathrm{a}$ & $0.69 \mathrm{a}$ \\
\hline & Peptide E & $78.9 \mathrm{a}$ & $11.30 \mathrm{a}$ & $1.68 \mathrm{a}$ & $2.34 \mathrm{a}$ & $0.68 \mathrm{a}$ \\
\hline
\end{tabular}

Table 2. Physiological indexes of watermelon, wheat and maize leaves after field application of peptides A, $\mathrm{B}$ and E. All data were means of triplicate samples. The same letter within a column indicated no statistical significance at $\mathrm{P}<0.05$ as determined by the LSD test.

for the fate study implementation. In addition, microbial degradation of Cry1Ac protein may vary largely due to microbial diversity and population dynamics at various environmental conditions ${ }^{8,12,29-31}$. In the present study, pure Bt CrylAc and proteolytic enzyme, produced by Streptomyces griseus that was prevalent in soil, were used to identify specific Bt peptides.

As a conservative estimate of the level of Cryl Ac protein was $650 \mathrm{ng} / \mathrm{g}^{7}$, the corresponding level of peptides was less than $5.9 \times 10^{-9} \mathrm{M}$ in soil (the average molecular weight of amino acids was $110 \mathrm{~g} / \mathrm{mol}$ ). In the bacteria growth experiment, the applied peptide concentration was $500 \mathrm{ng} / \mathrm{mL}$, which was much greater than the reported concentration in soil. Our study initially revealed that no promoting or inhibiting effect of peptide hydrolyzed by $\mathrm{Bt}$ protein on the growth of soil functional bacteria. Peptides could also be nutrients for bacteria ${ }^{28-30}$, but the amount of added peptides in the medium was much less compared to the amount of peptone $\left(1.0 \times 10^{7} \mathrm{ng} /\right.$ $\mathrm{mL}$ ), which are sources of carbon and nitrogen for bacterial growth. The amount of Bt protein and its degraded peptides was also relatively low in soil, which such small amounts of peptides might not affect the growth of bacteria as a nutrient.

${ }^{125}$ I has a half-life of 60 days and has been widely used in labeling peptides and proteins ${ }^{38,39}$. The shelf life of radiolabels varies somewhat among the peptides iodinated. Both radiation damage and spontaneous deiodination probably contribute to the decreased radioactivity. Heber et al. ${ }^{40}$ discovered that the shelf life of radiolabels, ${ }^{125} \mathrm{I}$-labeled luliberin, corticotropin, calcitonin and parathyrin at $10^{\circ} \mathrm{C}$ is $3-6,3-4,2$ and 2 weeks, respectively. The aim of the present study was to verify if any peptides derived from Bt protein can be transferred to the intercrops of Bt-cotton. Watermelon, wheat and maize are the most common intercrops of Bt-cotton in China. Peptides containing tyrosine or histidine can easily undergo the iodine labeling reaction. In the Bt Cryl Ac 
protein amino acid sequence, the previous amino acid of peptide B is tyrosine. So tyrosine was added to the $N$-terminal of peptide B, and peptide YTNPVLEN was synthesized for ${ }^{125} \mathrm{I}$ labeling. The maximal content of the ${ }^{125} \mathrm{I}$-peptide $\left({ }^{125} \mathrm{I}\right.$-peptide solution of $\left.10.0 \mu \mathrm{Ci} / \mathrm{L}\right)$ was about $1.286 \times 10^{-16} \mathrm{~mol} / \mathrm{cm}^{3}$ in small-pots in the present study. This value was significantly smaller than the conservatively estimated level $\left(5.9 \times 10^{-9} \mathrm{M}\right)$ of peptides deriving from Bt toxins in soil. In all treatment groups, notable radioactivity increase had been observed in both wheat and watermelon seedlings. These indicate that the metabolic peptides of Bt Cry1Ac from transgenic plant in soil could transfer to intercrops. The peptide transporters including oligopeptide transporters (OPTs) can transport di, tripe, tetra- and penta-peptides in plants ${ }^{41}$. The transporters of larger peptide ( $>5$ amino acids) are still unclear. The exogenously treatment of synthetic peptide RALF ( $5 \mathrm{kDa}, \sim 50$ amino acids) inhibited the root growth of tomato and Arabidopsis thaliana ${ }^{42}$. Similarly, exogenously supplied CLE peptides inhibited the formation of protoxylem vessels ${ }^{43}$. These results indicate that the larger peptide ( $>5$ amino acids) may be transferred from the surroundings to the plant, which is consistent with our results.

The ${ }^{125} \mathrm{I}$-peptide content in wheat and watermelon seedlings was about $1.0 \times 10^{-17}$ to $1.0 \times 10^{-14} \mathrm{~mol} / \mathrm{g}$. Radioactivity values in stems were larger than those in leaves commonly. The plants absorb nutrients from the roots, transport them to the stem, and then to the leaves. One hour after application, the ${ }^{125}$ I-peptide existed mainly in stems and a little has been transferred into leaves. In general, the radioactivity value in wheat tissues was higher than that in watermelon. This was because wheat seedlings had larger leaf surface area and more developed root system during the experimental stage. As the root pressure and leaf transpiration are the main impetus for nutrient transport and wheat seedlings had stronger transpiration and root pressure ${ }^{44}$, which resulted in the much higher radioactivity value in wheat seedling tissues.

The radioactivity value of plant cultivated in sterile soil was significant higher than that in non-sterile soil. The chemical and physical properties of sterile soil have been altered heavily ${ }^{45-48}$. Autoclaving soil has been shown to influence soil chemical properties ${ }^{45}$. The extractable $\mathrm{Mn}, \mathrm{N}, \mathrm{P}, \mathrm{S}, \mathrm{NH}_{4}-\mathrm{N}, \mathrm{NO}_{3}-\mathrm{N}$, organic matter, available $\mathrm{P}$, water-soluble amino acids and carbohydrate levels increased significantly, but $\mathrm{Al}$ and $\mathrm{Fe}$ and trace element levels decreased in autoclaved soil ${ }^{45,47,48}$. Others have found that autoclaving can change the surface charge of pores in sandstone and reduce the surface area of clay ${ }^{4-48}$. The decrease of adsorption capacity of sterile soil particles may lead to easier translocation of peptides from soil into plant root. The soil sterilization can effectively kill microorganisms and inactivate all enzymes. This treatment was an effective method to prevent ${ }^{125}$ I-peptide from hydrolysis in soil in the present study.

Intercrop and rotation patterns have the potential to increase total system productivity, improve product quality, make full use of resources, resist pests, and enhance weed management and plant disease control ${ }^{49,50}$. Intercropping of cotton and wheat is a major application of multiple cropping, and plays an important role in combining food security and farmer's income ${ }^{25}$. Intercropping of cotton and watermelon has been practiced in some area. In this study, peptides had no significant effect on main physiological indexes (total soluble protein, total sugar, superoxide and dismutase) of wheat, watermelon and maize except that peptide B has a significant increase on chlorophyll b content in watermelon seedlings. Plant peptides including systemin, clavata3/embryo surrounding region-related (CLE) peptides and rapid alkalization factor (RALF) act as key components of cellto-cell communication ${ }^{42,43}$. These active signaling peptides regulate plant growth and development such as protoxylem vessel, stem cell differentiation and root growth and cause morphological change ${ }^{42,43,51}$. However, the phenotype of peptide B-treated watermelon seedling was not observed, which showed that peptide B maybe a non-bioactive peptide. Nakaminami et al. ${ }^{52}$ reported the external application of a hormone-like peptide AtPep3 ( 30 amino acids) on Arabidopsis seedlings could affect the biosynthesis of chlorophyll. The chlorophyll content was significantly increased by $200-300 \%$ in comparison with the untreated control. While the chlorophyll b content was only increased by $9.1 \%$ in peptide B-treated seedlings, the effects of peptide B on chlorophyll b or other physiological indexes must be further verified. Identical peptide B (YTNPVLEN) sequence was also found in the ECF transporter S component (Desulfosporosinus sp. FKA, Genbank No. WP_088189292.1). However, the $C$-terminal of this peptide is leucine instead of phenylalanine in Bt Cry1 Ac (YTNPVLENF).

In conclusion, Bt CrylAc protein was degraded into peptides by pronase secreted from Streptomyces griseus. The peptides can transfer into intercropping crops in the next season. The size or types of peptides that can be up taken by crops require further investigation. In general, the transferred peptides have shown no obvious influence on the crops or bacteria. This study provides a new view of GMO risk assessment methodology.

\section{Materials and methods}

Bacterial growth media. $\mathrm{N}$-fixing bacteria were cultured with Waksman 77 medium (medium I, Glucose $10.0 \mathrm{~g}, \mathrm{MgSO}_{4} \cdot 7 \mathrm{H}_{2} \mathrm{O} 0.2 \mathrm{~g}, \mathrm{~K}_{2} \mathrm{HPO}_{4} 0.4 \mathrm{~g}, \mathrm{NaCl} 0.2 \mathrm{~g}, 2$ drops of $1 \%(w / v) \mathrm{FeCl}_{3}$ and $1 \%(w / v) \mathrm{MnSO}_{4}$ solution, $1 \%(w / v)$ Congo Red solution $5 \mathrm{~mL}$, agar $18 \mathrm{~g}$, distilled water $1000 \mathrm{~mL}, \mathrm{pH}$ 7.0.). Organic phosphate-dissolving bacteria were cultured with Menkina medium (medium II, Glucose $10.0 \mathrm{~g},\left(\mathrm{NH}_{4}\right)_{2} \mathrm{SO}_{4} 0.5 \mathrm{~g}, \mathrm{NaCl} 0.3 \mathrm{~g}, \mathrm{KCl}$ $0.3 \mathrm{~g}, \mathrm{MgSO}_{4} \cdot 7 \mathrm{H}_{2} \mathrm{O} 0.3 \mathrm{~g}, \mathrm{FeSO}_{4} \cdot 7 \mathrm{H}_{2} \mathrm{O} 0.03 \mathrm{~g}, \mathrm{MnSO}_{4} \cdot 4 \mathrm{H}_{2} \mathrm{O} 0.03 \mathrm{~g}$, lecithin $0.2 \mathrm{~g}, \mathrm{CaCO}_{3} 5.0 \mathrm{~g}$, agar $18.0 \mathrm{~g}$, distilled water $1000 \mathrm{~mL}, \mathrm{pH}$ 7.0-7.5.) and liquid medium (medium III, Glucose $10.0 \mathrm{~g},\left(\mathrm{NH}_{4}\right)_{2} \mathrm{SO}_{4} 0.5 \mathrm{~g}, \mathrm{NaCl}$ $0.3 \mathrm{~g}, \mathrm{KCl} 0.3 \mathrm{~g}, \mathrm{MgSO}_{4} \cdot 7 \mathrm{H}_{2} \mathrm{O} 0.3 \mathrm{~g}, \mathrm{FeSO}_{4} \cdot 7 \mathrm{H}_{2} \mathrm{O} 0.03 \mathrm{~g}, \mathrm{MnSO}_{4} \cdot 4 \mathrm{H}_{2} \mathrm{O} 0.03 \mathrm{~g}$, lecithin $0.2 \mathrm{~g}, \mathrm{CaCO}_{3} 5.0$ g, yeast extract $0.4 \mathrm{~g}$, distilled water $1000 \mathrm{~mL}, \mathrm{pH}$ 7.0-7.5.). Potassium-dissolving bacteria were cultured with Aleksandrov's medium (medium IV, Sucrose $5.0 \mathrm{~g}, \mathrm{MgSO}_{4} \cdot 7 \mathrm{H}_{2} \mathrm{O} 0.5 \mathrm{~g}, \mathrm{CaCO}_{3} 0.1 \mathrm{~g}, \mathrm{Na}_{2} \mathrm{HPO}_{4} \cdot 12 \mathrm{H}_{2} \mathrm{O} 2.0 \mathrm{~g}, \mathrm{FeCl}_{3} \cdot 6 \mathrm{H}_{2} \mathrm{O}$ $0.005 \mathrm{~g}$, potassium-bearing rock powders $1.0 \mathrm{~g}$, agar $18.0 \mathrm{~g}$, distilled water $1000 \mathrm{~mL}, \mathrm{pH} 7.0-7.5$ ) and Beef extract-peptone medium (medium V, Beef extract 3.0 g, peptone $10.0 \mathrm{~g}, \mathrm{NaCl} 1.0$ g, distilled water $1000 \mathrm{~mL}, \mathrm{pH}$ 7.0-7.2.). All of the above media were autoclaved at $115^{\circ} \mathrm{C}$ for $30 \mathrm{~min}$.

Enzymolysis of Cry1Ac protein and identification of small peptides. One mg of Bt CrylAc protein (Youlong Biotech LLC, Shanghai, China) was dissolved in $4.0 \mathrm{~mL}$ phosphate buffer solution (PBS, $10 \mathrm{mM}, \mathrm{pH}$ 
7.4), followed by addition of $400 \mu \mathrm{L}$ pronase solution $(0.1 \mathrm{mg} / \mathrm{mL}$, Sigma-Aldrich, St. Louis, MO, USA). After $0,1,2,3,4$ and $5 \mathrm{~h}$ of incubation at $37^{\circ} \mathrm{C}$, an aliquot of enzymatic hydrolyzate was sampled for sodium dodecyl sulfate polyacrylamide gel (SDS-PAGE, 12\%) analysis. After enzyme hydrolysis for $5 \mathrm{~h}$, the $\mathrm{pH}$ of buffer was adjusted to 2.0 with $2 \mathrm{M} \mathrm{HCl}$ to deactivate pronase. The enzymatic digest was filtered at a molecular weight cutoff of $3000 \mathrm{Da}$ (Merck Millipore, Germany) to remove large-molecular-weight peptides. The filtrate was collected in a tube and then mixed with $5.0 \mathrm{~mL}$ of aqueous formic acid (FA, $0.1 \%, \mathrm{v} / \mathrm{v})$. The mixture was desalted with a $\mathrm{C}_{18}$ desalination column, lyophilized and then reconstituted in $300 \mu \mathrm{L} 0.1 \%$ FA for nano liquid chromatography mass spectrometry analysis (nanoLC-MS/MS) ${ }^{53}$.

The nanoLC-MS/MS analyses were performed on a nano liquid chromatograph (Proxeon Biosystems) Q-Exactive mass spectrometer (Thermo Finnigan) system. The peptide mixtures were pre-concentrated onto a Thermo scientific EASY $\mathrm{C}_{18}$ column $(2 \mathrm{~cm} \times 100 \mu \mathrm{m}, 5 \mu \mathrm{m})$ and separated on a Thermo scientific EASY $\mathrm{C}_{18}$ column $(100 \mathrm{~mm} \times 75 \mu \mathrm{m}, 3 \mu \mathrm{m})$ by gradient elution. The mobile phase consisted of $0.1 \% \mathrm{FA}$ (solution A) and $84 \%$ aqueous acetonitrile containing $0.1 \% \mathrm{FA}$ (solution B) and programmed by increasing solution B from 0 to $50 \%(\mathrm{v} / \mathrm{v})$ in $50 \mathrm{~min}$, to $100 \%$ in $4 \mathrm{~min}$, and then remained at $100 \%$ for $6 \mathrm{~min}$. The flow rate was $250 \mathrm{~nL} / \mathrm{min}$.

The mass spectrometer was operated in positive ion mode and higher-energy collisional dissociation (HCD) by using a data-dependent top 10 method to dynamically choose the most abundant precursor ions $(300-1800 \mathrm{~m} / z)$ from the survey scan. Automatic gain control (AGC) target was set at 3e6, and maximum inject time at $10 \mathrm{~ms}$. Determination of the target value was based on predictive AGC. Dynamic exclusion duration was $20.0 \mathrm{~s}$. Survey scans were acquired at a resolution of 70,000 at $\mathrm{m} / z 200$ and resolution for HCD spectra was set at 17,500 at $\mathrm{m} / z 200$, and isolation window was set at $2 \mathrm{~m} / z$. MS/MS maximum inject time was set at $60 \mathrm{~ms}$. Normalized collision energy was $27 \mathrm{eV}$ and the underfill ratio, which specified the minimum percentage of the target value likely to reach at maximum fill time, was defined as $0.1 \%$ on the Q-Exactive. The instrument was run in peptide recognition mode.

Raw MS/MS spectral data were searched using Mascot engine (Matrix Science, London, UK; version 2.2) against a Bt CrylAc protein amino acid sequence database. For peptide identification, the following options were used: Enzyme at none, and two missed cleavages permitted. The precursor mass tolerance was set at $20 \mathrm{ppm}$, MS/MS tolerance was set at $0.1 \mathrm{Da}$. The fixed modification was carbamidomethyl for cysteines, and the variable modification was oxidation for methionine. The false discovery rate (FDR) for peptides and modification site was set at 0.01. A MaxQuant score was set at $\geq 20$.

The localization of large peptides. Both $N$-terminal amino acid sequencing and nanoLC-MS/MS analysis were used to confirm the large peptides. The $N$-terminal amino acid sequences of large peptides (bands 1 and 2 in Fig. 1a) in gel were analyzed by Edman method ${ }^{54}$. The PVDF membrane (Millipore, USA) was immersed in absolute methanol for $10 \mathrm{~s}$ followed by rinsing in distilled water and equilibration in transfer buffer (10 mM CAPS, $10 \%$ methanol, pH 11.0). The SDS-PAGE gels were blotted at $250 \mathrm{~mA}$ for $1.0 \mathrm{~h}$ using the DALT Blotting Kit (Bio-Rad, USA). The PVDF blots were then washed twice by distilled water, stained with Coomassie brilliant blue (0.05\% Coomassie brilliant blue R-250, 50\% methanol, 9.2\% acetic acid in distilled water) for $45 \mathrm{~min}$, and destained in absolute methanol for $1.0 \mathrm{~min}$.

The protein spots were cut from dry PVDF membrane and placed in small tubes. $600 \mu \mathrm{L} 0.1 \%$ trifluoroacetic acid was added into every tube. Then the tubes were incubated in a thermostatic shaker (room temperature, $600 \mathrm{rpm}$ ) for $1.0 \mathrm{~min}$, removing the supernatant, repeated 3 times. The membranes were air-dried, cut into $0.5 \mathrm{~cm}^{2}$ in size and then loaded in the blot cartridge. The sequences were analyzed on an automatic peptide sequencing machine (PPSQ-33A, Shimadzu) at APTbiotech (Shanghai, China).

Radioactive iodination of the octa amino acid peptide YTNPVLEN. To track the translocation of derived peptide, synthetic peptides (SBS Genetech Co., Ltd, Beijing, China) are labeled with radioactive elements. ${ }^{125} \mathrm{I}$ is commonly used for labelling peptides on tyrosine ${ }^{55,56}$. There was a tyrosine previous to the $N$-terminal of peptide $\mathrm{B}\left(\mathrm{H}_{2} \mathrm{~N}\right.$-TNPVLEN-COOH) in the Bt CrylAc amino acid sequence. So peptide $\mathrm{H}_{2} \mathrm{~N}-\mathrm{YTNPVLEN}-\mathrm{COOH}$ was synthesized for iodination labelling by chloramine-T method ${ }^{39}$ at the State Key Laboratory of Radioactive Chemical Drugs of Beijing Normal University. An aliquot of $100 \mu \mathrm{L}$ of chloramine$\mathrm{T}(0.99 \mu \mathrm{g} / \mu \mathrm{L})$ and $1.0 \mathrm{mCi}$ of Na${ }^{125} \mathrm{I}(18.5 \mathrm{MBq})$ were added into $2.5 \mathrm{~mL}$ of peptide solution $(40 \mu \mathrm{g} / \mathrm{mL})$. After stirred for $5 \mathrm{~min}$ at room temperature, $100 \mu \mathrm{L}$ of sodium pyrosulfite (Acfa Aesar, Beijing, China) solution $(1.67 \mu \mathrm{g} / \mu \mathrm{L})$ was added to stop the reaction. The mixture was loaded on SCL-10Avp high performance liquid chromatograph (Shimadzu, Japan), separated by a semi-preparative Venusil MP C-18 column $(10 \mathrm{~mm} \times 250 \mathrm{~mm}$, Bonna-Agela Technologies). The radiolabeled peptide was eluted with acetonitrile at a flow rate of $2.0 \mathrm{~mL} / \mathrm{min}$ and monitored by a UV detector $(254 \mathrm{~nm})$. The fraction at the retention time period of 7.6-8.3 min was collected. The radioactivity was determined by a Gamma Counter (Wallac, USA). The ${ }^{125}$ I-peptide was purified for the following experiment.

Cultivation of crop seedlings. The soil, in which non-transgenic crops were previously grown, was collected from China Agricultural University's experimental field $\left(\mathrm{N} 40^{\circ} 01^{\prime}, \mathrm{E} 116^{\circ} 16^{\prime}\right)$ at a depth of $0-15 \mathrm{~cm}$. The soil had a pH of 7.9 and was consisted of $48.8 \%$ sand, $48.2 \%$ silt, $3.0 \%$ clay, $2.6 \%$ organic matter, $0.16 \%$ total nitrogen, $60.1 \mathrm{mg} / \mathrm{kg}$ available phosphorus and $95.5 \mathrm{mg} / \mathrm{kg}$ available potassium. It was air-dried at room temperature and used to grow plant seedlings.

Wheat and watermelon seeds were immersed in sterile deionized water at $37^{\circ} \mathrm{C}$ for $5 \mathrm{~h}$ and $10 \mathrm{~h}$, respectively. The seeds were spread evenly on the germinating paper $(25 \times 38 \mathrm{~cm})($ OR 97321 , Hoffman Manufacturing Inc., Albany, USA) in germination boxes. The wheat and watermelon seeds were sprouted 4 and 2 days, respectively, in a DRX-450C growth chamber (Ningbo Safe LLC., Zhejiang, China) set at $28 \pm 1{ }^{\circ} \mathrm{C}$ and humidity at $70 \pm 5 \%$ 
( $12 \mathrm{~h} / 12 \mathrm{~h}$, light/dark circular). After that, the seedlings were transplanted into small pots $\left(350 \mathrm{~cm}^{3}, 20\right.$ seedlings per pot), which contained sterile or non-sterile soil. The soil sterilization process was as follows: the soil powder was tiled in an aluminum box, its depth was approximately $2 \mathrm{~cm}$. They were autoclaved at $121^{\circ} \mathrm{C}$ for $3 \mathrm{~h}$, and were dried at $103{ }^{\circ} \mathrm{C}$ for $3 \mathrm{~h}^{45}$. The pots were kept in the growth chamber 6 days for watermelon and 5 days for wheat.

Fertilization of ${ }^{125}$ I-peptide and measurement of radioactivity. Six days after wheat seedlings and 5 days after watermelon seedlings transplant, the seedlings were respectively fertilized with ${ }^{125}$ I-peptide solution. Sixteen pots of watermelon and wheat seedlings, respectively, were divided into four groups. The first group which fertilized with isometric sterile deionized water was served as the control group. The other three treatment groups were added with $10.0 \mathrm{~mL}^{125} \mathrm{I}$-peptide solution of $0.1,1.0,10.0 \mu \mathrm{Ci} / \mathrm{L}$, respectively. In each group, one pot was with sterile soil and other three pots were with non-sterile soil. The radioactive solution was squirted out from an injector to the surface of soil to make sure that no solution was adhered to plant surface. Those seedlings were cultivated in the growth chamber set at $25 \pm 1{ }^{\circ} \mathrm{C}$, and $10 \mathrm{~h} / 14 \mathrm{~h}$ of light/dark circular.

At set intervals, one plant was sampled from every small-pot after fertilization. The leaves and stems were cut off and weighed, respectively. The radioactive intensity of those tissues was measured by WIZARD2 Automatic Gamma Counter for 2 days. All data were recorded automatically.

Effect of peptides on soil functional bacteria. Colonies of organic phosphate-dissolving bacteria, nitrogen-fixing bacteria and potassium-dissolving bacteria were isolated from the soil of experimental field as previously described ${ }^{10,57}$ and the colonies were stored at $4{ }^{\circ} \mathrm{C}$ until further use. Bacterial species were identified by alignment of partial 16S rRNA gene sequences against the GenBank database ${ }^{36,58}$. The identification criteria described by Joseph ${ }^{59}$ were adopted.

Organic phosphate-dissolving bacteria were activated in beef extract-peptone medium. The bacteria were cultured in a thermostatic shaker (JC-211B, Jingchang Yiqi, Shanghai, China) at $28^{\circ} \mathrm{C}$ under shaking $160 \mathrm{rpm}$. The optical density (OD, $\lambda=600 \mathrm{~nm}$ ) of the culture was measured with a UV-2550 spectrophotometer (Shimadzu, Suzhou, China). After $\mathrm{OD}_{600}$ of the medium reached to $1.0,40 \mu \mathrm{L}$ of the bacteria was transferred into $40 \mathrm{~mL}$ of liquid medium (medium III). Meanwhile, the synthesized peptides A, B and $\mathrm{E}$ were added in medium to a series of final concentrations of $0,5,50,500 \mathrm{ng} / \mathrm{mL}$. Every group was in triplicate. The bacteria were cultured on the thermostatic shaker again. The procedure of bacteria activation and peptides addition for culturing nitrogenfixing bacteria was the same as organic phosphate-dissolving bacteria, while beef extract-peptone medium was used for bacteria growth evaluation study. $\mathrm{OD}_{600}$ values were determined to evaluate the effect of peptides on the bacterial growth.

The peptides addition for culturing potassium-dissolving bacteria was the same as above. The final concentration of the three peptides was all $500 \mathrm{ng} / \mathrm{mL}$ in solid Aleksandrov's medium. Every group was in triplicate. A colony was dissolved in sterile distilled water to an appropriate concentration, and $100 \mu \mathrm{L}$ of the dilution was used to inoculate each plate. All plates were incubated in growth chamber at $28^{\circ} \mathrm{C}$. Four days later, the number of strain colonies was counted. The effect of peptides on potassium-dissolving bacteria was evaluated based on the number of colonies.

Effect of peptides on wheat, watermelon and maize physiology. Wheat seedlings in small pots were cultivated in the DRX-450C growth chamber set at $28 \pm 1{ }^{\circ} \mathrm{C}$ and humidity at $70 \pm 5 \%(12 \mathrm{~h} / 12 \mathrm{~h}$, light/ dark). Twenty-four pots of wheat seedlings were divided into four groups. When the height of seedlings was about $15 \mathrm{~cm}$, each of the three treatment groups was sprayed $2.0 \mathrm{~mL}$ of $1.0 \mu \mathrm{g} / \mathrm{mL}$ of peptides (A, B and E) solution, while the control group was sprayed with the same volume of sterile deionized water. The spraying was repeated one week later. Watermelon seedlings and maize (Zea mays L.) seedlings were planted at Shangzhuang Experimental Field ( $40^{\circ} 08^{\prime}, \mathrm{E} 116^{\circ} 10^{\prime}$, Beijing, China). When the length of watermelon vines was about $30 \mathrm{~cm}$ and the height of maize stalks was about $1.2 \mathrm{~m}$, each watermelon and maize plant was sprayed $4.0 \mathrm{~mL}$ of $1.0 \mu \mathrm{g} / \mathrm{mL}$ peptides (A, B and $\mathrm{E}$ ) solution.

One week after the second spraying, the leaves were collected and stored at $-40{ }^{\circ} \mathrm{C}$ before further study. The physiological indexes of total soluble protein, total sugar, chlorophyll and SOD were determined as described previously ${ }^{8,60-62}$.

Statistical analyses. To assess the effect of peptides on bacteria and crops, the $\mathrm{OD}_{600}$ value of bacterial medium, the numbers of bacterial colonies and physiological indexes of crops were statistically analyzed with Duncan's Multiple Range Test at a significance level of 5\% in SPSS 17 (Chicago, IL, USA).

Received: 29 January 2020; Accepted: 11 August 2020

Published online: 14 October 2020

\section{References}

1. Huang, J., Hu, R., Pray, C., Qiao, F. \& Rozelle, S. Biotechnology as an alternative to chemical pesticides, a case study of Bt cotton in China. Agric. Econ. 29, 55-67. https://doi.org/10.1111/j.1574-0862.2003.tb00147.x (2003).

2. Icoz, I. \& Stotzky, G. Cry3Bb1 protein from Bacillus thuringiensis in root exudates and biomass of transgenic corn does not persist in soil. Transgenic. Res. 17, 609-620. https://doi.org/10.1007/s11248-007-9133-8 (2008).

3. Zwahlen, C., Hilbeck, A., Gugerli, P. \& Nentwig, W. Degradation of the Cry1Ab protein within transgenic Bacillus thuringiensis corn tissue in the field. Mol. Ecol. 12, 765-775. https://doi.org/10.1046/j.1365-294X.2003.01767.x (2003). 
4. Losey, J. E., Rayor, L. S. \& Carter, M. E. Transgenic pollen harms monarch larvae. Nature 399, 214-215. https://doi. org/10.1038/20338 (1999).

5. Pont, B. \& Nentwig, W. Quantification of Bt-protein digestion and excretion by the primary decomposer Porcellio scaber, fed with two Bt-corn varieties. Biocontrol. Sci. Technol. 15, 341-352. https://doi.org/10.1080/09583150400016969 (2005).

6. Stotzky, G. Persistence and biological activity in soil of the insecticidal proteins from Bacillus thuringiensis, especially from transgenic plants. Plant Soil 266, 77-89. https://doi.org/10.1007/s11104-005-5945-6 (2004).

7. Head, G., Surber, J. B., Watson, J. A., Martin, J. W. \& Duan, J. J. No detection of CrylAc protein in soil after multiple years of transgenic Bt cotton (Bollgard) use. Environ. Entomol. 31, 30-36. https://doi.org/10.1603/0046-225x-31.1.30 (2002).

8. Wang, H., Ye, Q., Gan, J. \& Wu, L. Biodegradation of Cry1 Ab protein from Bt transgenic rice in aerobic and flooded paddy soils. J. Agric. Food. Chem. 55, 1900-1904. https://doi.org/10.1021/jf062924x (2007).

9. Tapp, H. \& Stotzky, G. Dot blot enzyme-linked immunosorbent assay for monitoring the fate of insecticidal toxins from bacillus thuringiensis in soil. Appl. Environ. Microb. 61, 602-609. https://doi.org/10.1016/S1075-9964(95)80457-9 (1995).

10. Rui, Y. K. et al. Changes of Bt toxin in the rhizosphere of transgenic Bt cotton and its influence on soil functional bacteria. World J. Microbiol Biotechnol. 21, 1279-1284. https://doi.org/10.1007/s11274-005-2303-z (2005).

11. Sims, S. R. \& Ream, J. E. Soil inactivation of the Bacillus thuringiensis subsp. kurstaki CryIIA insecticidal protein within transgenic cotton tissue: Laboratory microcosm and field studies. J. Agric. Food Chem. 45, 1502-1505. https://doi.org/10.1021/jf960647w (1997).

12. Crecchio, C. \& Stotzky, G. Biodegradation and insecticidal activity of the toxin from Bacillus thuringiensis subsp. kurstaki bound on complexes of montmorillonite-humic acids-A1 hydroxypolymers. Soil. Biol. Biochem. 33, 573-581. https://doi.org/10.1016/ S0038-0717(00)00199-1 (2001).

13. Crecchio, C. \& Stotzky, G. Insecticidal activity and biodegradation of the toxin from Bacillus thuringiensis subsp. kurstaki bound to humic acids from soil. Soil. Biol. Biochem. 30, 463-470. https://doi.org/10.1016/s0038-0717(97)00147-8 (1998).

14. Castaldini, M. et al. Impact of Bt corn on rhizospheric and soil eubacterial communities and on beneficial mycorrhizal symbiosis in experimental microcosms. Appl. Environ. Microb. 71, 6719-6729. https://doi.org/10.1128/aem.71.11.6719-6729.2005 (2005).

15. Donegan, K. K. et al. Microbial populations, fungal species diversity and plant pathogen levels in field plots of potato plants expressing the Bacillus thuringiensis var. tenebrionis endotoxin. Transgenic. Res. 5, 25-35. https://doi.org/10.1007/bf01979919 (1996).

16. Griffiths, B. S. et al. Soil microbial and faunal community responses to maize and insecticide in two soils. J. Environ. Qual. 35, 734-741. https://doi.org/10.2134/jeq2005.0344 (2006).

17. Koskella, J. S. \& Stotzky, G. Larvicidal toxins from Bacillus thuringiensis subspp. kurstaki, morrisoni (strain tenebrionis), and israelensis have no microbicidal or microbiostatic activity against selected bacteria, fungi, and algae in vitro. Can. J. Microbiol. 48, 262-267. https://doi.org/10.1139/w02-005 (2002).

18. Zwahlen, C., Hilbeck, A., Howald, R. \& Nentwig, W. Effects of transgenic Bt corn litter on the earthworm Lumbricus terrestris. Mol. Ecol. 12, 1077-1086 (2003).

19. Clark, B. W., Prihoda, K. R. \& Coats, J. R. Subacute effects of transgenic Cryl Ab Bacillus thuringiensis corn litter on the isopods Trachelipus rathkii and Armadillidium nasatum. Environ. Toxicol. Chem. 25, 2653-2661. https://doi.org/10.1897/05-471R.1 (2006).

20. Al-Deeb, M. A., Wilde, G. E., Blair, J. M. \& Todd, T. C. Effect of Bt corn for corn rootworm control on nontarget soil microarthropods and nematodes. Environ. Entomol. 32, 859-865. https://doi.org/10.1603/0046-225x-32.4.859 (2003).

21. Ahmad, A., Wilde, G. E. \& Zhu, K. Y. Detectability of coleopteran-specific Cry3Bb1 protein in soil and its effect on nontarget surface and below-ground arthropods. Environ. Entomol. 34, 385-394. https://doi.org/10.1603/0046-225x-34.2.385 (2005).

22. Turrini, A., Sbrana, C., Nuti, M. P., Pietrangeli, B. M. \& Giovannetti, M. Development of a model system to assess the impact of genetically modified corn and aubergine plants on arbuscular mycorrhizal fungi. Plant Soil 266, 69-75. https://doi.org/10.1007/ s11104-005-4892-6 (2004)

23. Baumgarte, S. \& Tebbe, C. C. Field studies on the environmental fate of the Cry1 Ab Bt-toxin produced by transgenic maize (MON810) and its effect on bacterial communities in the maize rhizosphere. Mol. Ecol. 14, 2539-2551. https://doi.org/10.1111/ j.1365-294X.2005.02592.x (2005).

24. James, C. Global Status of Commercialized Biotech/GM Crops: 2015. ISAAA Briefs No. 51. ISAAA: Ithaca, NY. (2015).

25. Zhang, L., van der Werf, W., Zhang, S., Li, B. \& Spiertz, J. H. J. Growth, yield and quality of wheat and cotton in relay strip intercropping systems. Field. Crop. Res. 103, 178-188. https://doi.org/10.1016/j.fcr.2007.06.002 (2007).

26. Dang, X. Y. et al. Uptake and conversion efficiencies of NPK and corresponding contribution to yield advantage in cotton-based intercropping systems. Chin. J. Eco-Agric. 20, 513-519. https://doi.org/10.3724/sp.j.1011.2012.00513 (2012).

27. Qiang, X. S., Sun, J. S., Liu, H., Ning, H. F. \& Wu, X. L. Effects of drip irrigation quota on yield and water productivity in watermeloncotton intercropping system. Trans. Chin. Soc. Agric. Eng. 32, 113-119. https://doi.org/10.11975/j.issn.1002-6819.2016.19.016 (2016).

28. Fiorito, T. M., Icoz, I. \& Stotzky, G. Adsorption and binding of the transgenic plant proteins, human serum albumin, $\beta$-glucuronidase, and Cry3Bb1, on montmorillonite and kaolinite: Microbial utilization and enzymatic activity of free and claybound proteins. Appl. Clay. Sci. 39, 142-150. https://doi.org/10.1016/j.clay.2007.07.006 (2008).

29. Koskella, J. \& Stotzky, G. Microbial utilization of free and clay-bound insecticidal toxins from Bacillus thuringiensis and their retention of insecticidal activity after incubation with microbes. Appl. Environ. Microbiol. 63, 3561-3568. https://doi.org/10.1016/ S0027-5107(97)00112-7 (1997).

30. Valldor, P., Miethling-Graff, R., Martens, R. \& Tebbe, C. C. Fate of the insecticidal Cryl Ab protein of GM crops in two agricultural soils as revealed by 14C-tracer studies. Appl. Microbiol. Biotechnol. 99, 7333-7341. https://doi.org/10.1007/s00253-015-6655-5 (2015).

31. Padmaja, T. et al. Degradation of the insecticidal toxin produced by Bacillus thuringiensis var. kurstaki by extracellular proteases produced by Chrysosporium sp.. J. Appl. Microbiol. 104, 1171-1181. https://doi.org/10.1111/j.1365-2672.2007.03644.x (2008).

32. Narahashi, Y. \& Yoda, K. Studies on proteolytic enzymes (pronase) of Streptomyces griseus K-I. J. Biochem. 73, 831-841. https:// doi.org/10.1093/oxfordjournals.jbchem.a130146 (1973).

33. Saxena, D. \& Stotzky, G. Bt toxin uptake from soil by plants. Nat. Biotechnol. 19, 199-199. https://doi.org/10.1038/85617 (2001).

34. Icoz, I., Andow, D., Zwahlen, C. \& Stotzky, G. Is the Cryl Ab protein from Bacillus thuringiensis (Bt) taken up by plants from soils previously planted with Bt corn and by carrot from hydroponic culture?. Bull. Environ. Contam. Toxicol. 83, 48-58. https://doi. org/10.1007/s00128-009-9760-2 (2009).

35. Venkateswerlu, G. \& Stotzky, G. Binding of the protoxin and toxin proteins of Bacillus thuringiensis subsp. kurstaki on clay minerals. Curr. Microbiol. 25, 225-233. https://doi.org/10.1007/BF01570723 (1992).

36. Tapp, H., Calamai, L. \& Stotzky, G. Adsorption and binding of the insecticidal proteins from bacillus-thuringiensis subsp kurstaki and subsp tenebrionis on clay-minerals. Soil. Biol. Biochem. 26, 663-679. https://doi.org/10.1016/0038-0717(94)90258-5 (1994).

37. Chen, S., Rillig, M. C. \& Wang, W. Improving soil protein extraction for metaproteome analysis and glomalin-related soil protein detection. Proteomics 9, 4970-4973. https://doi.org/10.1002/pmic.200900251 (2009).

38. Jeon, J. et al. Radiosynthesis and in vivo evaluation of [125 $\mathrm{I}] 2$-(4-iodophenethyl)-2-methylmalonic acid as a potential radiotracer for detection of apoptosis. J. Radioanal. Nucl. Chem. 308, 23-29. https://doi.org/10.1007/s10967-015-4346-4 (2015).

39. Németh, J. et al. ${ }^{125}$ I-labeling and purification of peptide hormones and bovine serum albumin. J. Radioanal. Nucl. Chem. 251, 129-133. https://doi.org/10.1023/A:1015062731674 (2002). 
40. Heber, D., Odell, W. D., Schedewie, H. \& Wolfsen, A. R. Improved lodinationof peptidesfor radioimmunoassay and membrane radioreceptor assay. Clin. Chem. 24, 796-799. https://doi.org/10.1093/clinchem/24.5.796 (1978).

41. Waterworth, W. M. \& Bray, C. M. Enigma variations for peptides and their transporters in higher plants. Ann. Bot. 98, 1-8. https ://doi.org/10.1093/aob/mcl099 (2006).

42. Pearce, G., Moura, D. S., Stratmann, J. \& Ryan, C. A. RALF, a 5-kDa ubiquitous polypeptide in plants, arrests root growth and development. PNAS 98, 12843-12847. https://doi.org/10.1073/pnas.261577598 (2001).

43. Kondo, Y. \& Fukuda, H. CLE peptides can negatively regulate protoxylem vessel formation via cytokinin signaling. Plant. Cell. Physiol. 52, 37-48. https://doi.org/10.1093/pcp/pcq129 (2011).

44. Yamaji, N. \& Ma, J. F. The node, a hub for mineral nutrient distribution in graminaceous plants. Trends Plant Sci. 19, 556-563. https://doi.org/10.1016/j.tplants.2014.05.007 (2014).

45. Bottomley, P. S., Angle, J. S., Weaver, R. W., Wolf, D. C. \& Skipper, H. D. Soil Sterilization. In Methods of Soil Analysis: Part 2. Microbiological and Biochemical Properties. https://doi.org/https://doi.org/10.2136/sssabookser5.2.c3 (1994).

46. Jenneman, G. E. et al. Effect of sterilization by dry heat or autoclaving on bacterial penetration through berea sandstone. Appl. Environ. Microbiol. 51, 39-43. https://doi.org/10.1016/0141-4607(86)90026-0 (1986).

47. Wolf, D. C., Dao, T. H., Scott, H. D. \& Lavy, T. L. Influence of sterilization methods on selected soil microbiological, physical, and chemical properties. J. Environ. Qual. 18, 39-44. https://doi.org/10.2134/jeq1989.00472425001800010007x (1989).

48. Eno, C. F. \& Popenoe, H. Gamma radiation compared with steam and methyl bromide as a soil sterilizing agent. Soil. Sci. Soc. Am. J. 28, 533-535. https://doi.org/10.2136/sssaj1964.03615995002800040024x (1964).

49. Ma, X. M. et al. Assessment of cotton aphids, Aphis gossypii, and their natural enemies on aphid-resistant and aphid-susceptible wheat varieties in a wheat-cotton relay intercropping system. Entomol. Exp. Appl. 121, 235-241. https://doi.org/10.111 1/j.1570-8703.2006.00484.x (2006).

50. Zhang, L. et al. Light interception and utilization in relay intercrops of wheat and cotton. Field. Crop. Res. 107, 29-42. https://doi. org/10.1016/j.fcr.2007.12.014 (2008).

51. Ito, Y. et al. Dodeca-cle peptides as suppressors of plant stem cell differentiation. Science 313, 842-845. https://doi.org/10.1126/ science.1128436 (2006).

52. Nakaminami, K. et al. AtPep3 is a hormone-like peptide that plays a role in the salinity stress tolerance of plants. PNAS 115, 5810-5815 (2018).

53. Baker, M. et al. Site-specific N-glycosylation characterization of windmill palm tree peroxidase using novel tools for analysis of plant glycopeptide mass spectrometry data. J. Proteome Res. 15, 2026-2038. https://doi.org/10.1021/acs.jproteome.6b00205 (2016).

54. Jos, R. et al. Identification of two-dimensionally separated human cerebrospinal fluid proteins by $\mathrm{N}$-terminal sequencing, matrixassisted laser desorption/ionization-mass spectrometry, nanoliquid chromatography-electrospray ionization-time of flight-mass spectrometry, and tandem mass spectrometry. Electrophoresis 21, 2266-2283 (2000).

55. Tschopp, F. A. et al. Calcitonin gene-related peptide and its binding sites in the human central nervous system and pituitary. Proc. Natl. Acad. Sci. USA 82, 248-252. https://doi.org/10.1073/pnas.82.1.248 (1985).

56. Swanson, J. Studies on gonococcus infection. XVIII. 125I-labeled peptide mapping of the major protein of the gonococcal cell wall outer membrane. Infect. Immun. 23, 799-810. https://doi.org/10.1128/IAI.23.3.799-810.1979 (1979).

57. Davis, K. E. R., Joseph, S. J. \& Janssen, P. H. Effects of growth medium, inoculum size, and incubation time on culturability and isolation of soil bacteria. Appl. Environ. Microbiol. 71, 826-834. https://doi.org/10.1128/aem.71.2.826-834.2005 (2005).

58. Sait, M., Hugenholtz, P. \& Janssen, P. H. Cultivation of globally distributed soil bacteria from phylogenetic lineages previously only detected in cultivation-independent surveys. Environ. Microbiol. 4, 654-666. https://doi.org/10.1046/j.1462-2920.2002.00352.x (2002).

59. Joseph, S. J., Hugenholtz, P., Sangwan, P., Osborne, C. A. \& Janssen, P. H. Laboratory cultivation of widespread and previously uncultured soil bacteria. Appl. Environ. Microbiol. 69, 7210-7215. https://doi.org/10.1128/aem.69.12.7210-7215.2003 (2003).

60. Bradford, M. M. A rapid and sensitive method for the quantitation of microgram quantities of protein utilizing the principle of protein-dye binding. Anal. Biochem. 72, 248-254. https://doi.org/10.1016/0003-2697(76)90527-3 (1976).

61. Lorenzen, C. J. Determination of chlorophyll and pheopigments: Spectrophotometric equations. Limnol. Oceanogr. 12, 343-346. https://doi.org/10.2307/2833053 (1967).

62. Sun, Y., Oberley, L. W. \& Li, Y. A simple method for clinical assay of superoxide dismutase. Clin. Chem. 34, 497-500. https://doi. org/10.0000/PMID3349599 (1988)

\section{Acknowledgements}

We thank Prof. Huabei Zhang for the help on the isotope tracer experiment in Beijing Normal University. The authors are grateful to Prof. Qing X. Li (University of Hawaii, Mānoa, USA) for review of the manuscript. This work was funded by the National Natural Science Foundation of China (31271649).

\section{Author contributions}

X.J.C. and B.M.W. conceived the study design; W.Z. and Z.C. conducted the experiments; W.Z., Z.C., and M.W. analyzed the results, W.Z., Z.C., X.J.C., and B.M.W. wrote the final manuscript. All authors reviewed the manuscript.

\section{Competing interests}

The authors declare no competing interests.

\section{Additional information}

Supplementary information is available for this paper at https://doi.org/10.1038/s41598-020-73375-8.

Correspondence and requests for materials should be addressed to X.C. or B.W.

Reprints and permissions information is available at www.nature.com/reprints.

Publisher's note Springer Nature remains neutral with regard to jurisdictional claims in published maps and institutional affiliations. 
(c) (i) Open Access This article is licensed under a Creative Commons Attribution 4.0 International cc) License, which permits use, sharing, adaptation, distribution and reproduction in any medium or format, as long as you give appropriate credit to the original author(s) and the source, provide a link to the Creative Commons licence, and indicate if changes were made. The images or other third party material in this article are included in the article's Creative Commons licence, unless indicated otherwise in a credit line to the material. If material is not included in the article's Creative Commons licence and your intended use is not permitted by statutory regulation or exceeds the permitted use, you will need to obtain permission directly from the copyright holder. To view a copy of this licence, visit http://creativecommons.org/licenses/by/4.0/.

(C) The Author(s) 2020 